\title{
Variant NAXOS-Carvajal Syndrome with Rare Additional Features of Systemic Bulla and Brittle Nails: A Case Report and Literature Review
}

\author{
Takanori Sato, Sho Okada, Togo Iwahana and Yoshio Kobayashi
}

\begin{abstract}
:
Skin abnormalities are often indicative of cardiovascular diseases. Such a disease entity is called cardiocutaneous syndrome; however, the details regarding the involvement of bulla and nails remain largely unclear. A 49-year-old man with systemic bulla was admitted for heart failure. His bulla had previously been diagnosed as epidermolysis bullosa, but no known gene mutations for it had been identified. He had a triad of palmoplantar keratosis, curly and fine hair, and cardiomyopathy, which are characteristic of NAXOS-Carvajal syndrome. This case highlights the fact that bulla and brittle nails can accompany NAXOS-Carvajal syndrome, showing that these extra-cardiac findings can help identify otherwise overlooked serious cardiac conditions.
\end{abstract}

Key words: Cardiocutaneous syndrome, NAXOS-Carvajal syndrome, systemic bulla, brittle nails, cardiomyopathy, epidermolysis bullosa

(Intern Med 60: 1119-1126, 2021)

(DOI: 10.2169/internalmedicine.5899-20)

\section{Introduction}

Like a diagonal earlobe crease indicating atherosclerotic cardiovascular disease, apparently isolated skin abnormalities can be a clue suggesting systemic disease (1). Specifically, conditions in which cardiac and skin disorders coexist are termed cardiocutaneous syndromes (CCS), regardless of the degree of causality (2). This disease entity includes NAXOS disease and Carvajal syndrome, or NAXOS-Carvajal syndrome, in which cardiomyopathy of the right, left, or both ventricles occurs with hyperkeratosis and woolly hair in a hereditary manner $(3,4)$. Various gene mutations in the desmosome complex have been identified as common underlying causes of these diseases, with or without additional features (5-7), although several unidentified genes remain.

We herein report a novel familial case demonstrating the NAXOS-Carvajal phenotype with rare additional features of systemic bulla and brittle nails, in association with a literature review. To our knowledge, this is the first report on bullous cardiocutaneous syndrome that is unrelated to desmoplakin, the most critical protein in the desmosome com- plex.

\section{Case Report}

A 49-year-old man with dyspnea and systemic bulla was admitted to our hospital due to heart failure (HF). His skin lesions had persisted for more than 25 years and were diagnosed as epidermolysis bullosa (EB). He had no other comorbidities or allergies nor was he taking regular medicine. His parents were nonconsanguineous; however, he had a family history of heart disease, blisters, and curly hair (Fig. 1). His mother had died of HF. Two of his siblings died: one shortly after birth due to an unknown cause, and the other in his 20s due to dilated cardiomyopathy accompanied by systemic blisters. The other two siblings were alive and free of HF but suffered from premature senility and systemic blisters (one each). The patient's son had transposition of the great arteries without any skin disease.

On an examination, the patient's blood pressure was 144/ $102 \mathrm{mmHg}$, his heart rate was $95 \mathrm{bpm}$, and his oxygen saturation was $98 \%$. His jugular vein was distended, and pitting edema was observed. A mixture of non-purulent bulla in as- 


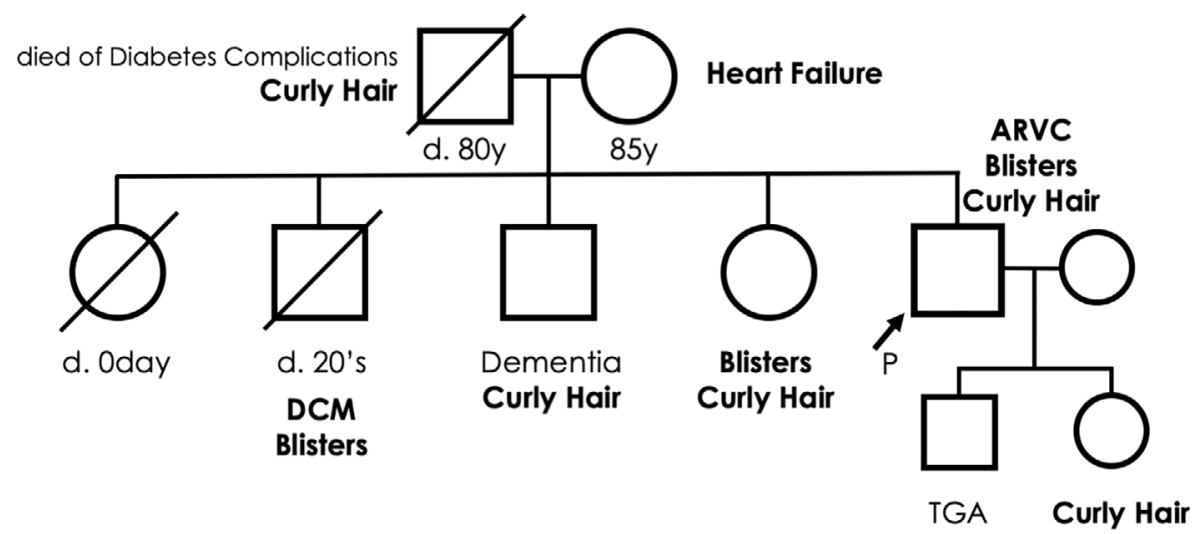

Figure 1. A family tree of the patient. Squares and circles indicate male and female sex, respectively. Arrow denotes the case. The oblique lines indicate deceased status. DCM: dilated cardiomyopathy, ARVC: arrhythmogenic right ventricular cardiomyopathy, TGA: transposition of the great arteries
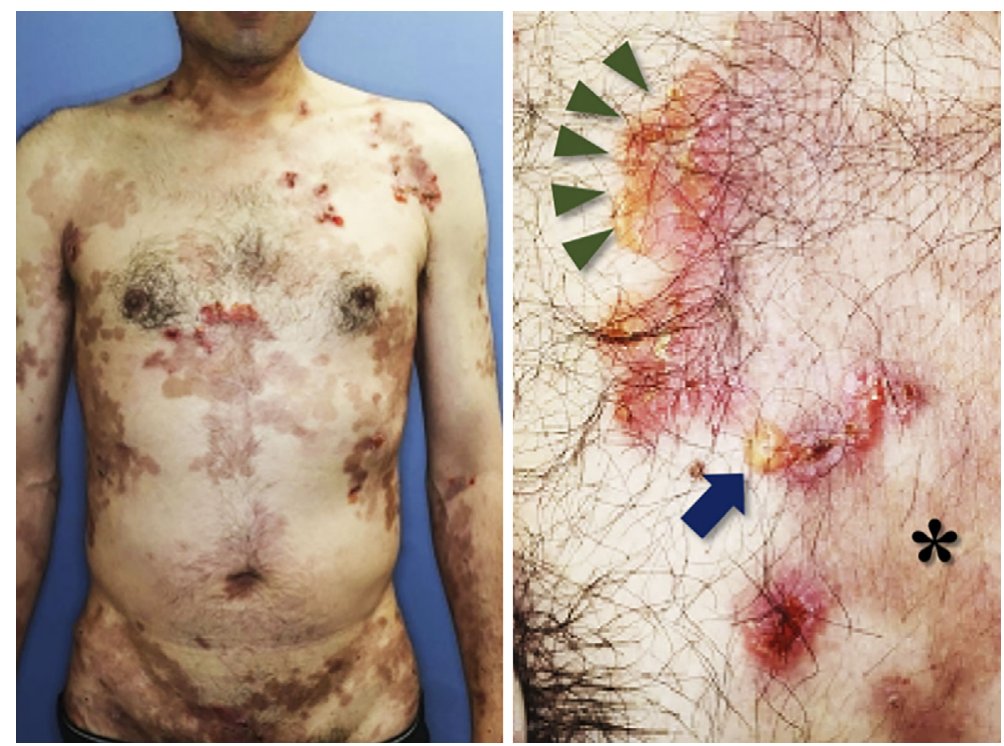

Figure 2. Skin lesions. The patient's skin lesions showing a mixture of blisters (arrow), erosion with erythema (arrowheads), and pigmentation (asterisk) throughout the body.

sociation with erosion, erythema, and pigmentation was found throughout his body (Fig. 2). His scalp hair had been fine and curly since birth. His hair had changed from black to brown during adolescence, as had his father's, his two siblings', and his daughter's. Mild focal keratosis was found on his palms and soles. His toenails were brittle and mostly detached. His fingernails were thick, white, and dystrophic (Fig. 3). The patient's teeth were normal.

His plasma brain natriuretic peptide (BNP) level was $2218 \mathrm{pg} / \mathrm{mL}$, serum creatinine $0.89 \mathrm{mg} / \mathrm{dL}$, and C-reactive peptide $0.88 \mathrm{mg} / \mathrm{dL}$. Serum antibodies for desmogleins and BP180 were negative.

Chest X-ray showed marked cardiomegaly and vascular redistribution (Fig. 4). An electrocardiogram revealed a low voltage, a first-degree atrioventricular block, and epsilon waves (Fig. 5a). On echocardiography, the right ventricle was dilated to $76 \mathrm{~mm}$, and its fractional area change was
$11 \%$ (Fig. 6). Severe tricuspid regurgitation was also observed. The left ventricle was enlarged to $63 \mathrm{~mm}$ with a flattened ventricular septum. The ejection fraction fell to $21 \%$.

In response to diuretic therapy with oral furosemide 40 $\mathrm{mg}$ /day and spironolactone $25 \mathrm{mg} /$ day, pulmonary and peripheral edema resolved within days. This patient then underwent a diagnostic workup for HF. Ventricular late potentials were positive on a signal-averaged electrocardiogram (Fig. 5b). Coronary angiography revealed no significant stenosis. Computed tomography and magnetic resonance imaging showed fatty infiltration into the ventricular septum and extensive fibrosis in the left ventricle, respectively (Fig. 7a, b). Endomyocardial biopsy specimens from the right ventricular septum exhibited fibro-fatty replacement in approximately half of the area (Fig. 7c). These findings collectively led to the definite diagnosis of arrhythmogenic 

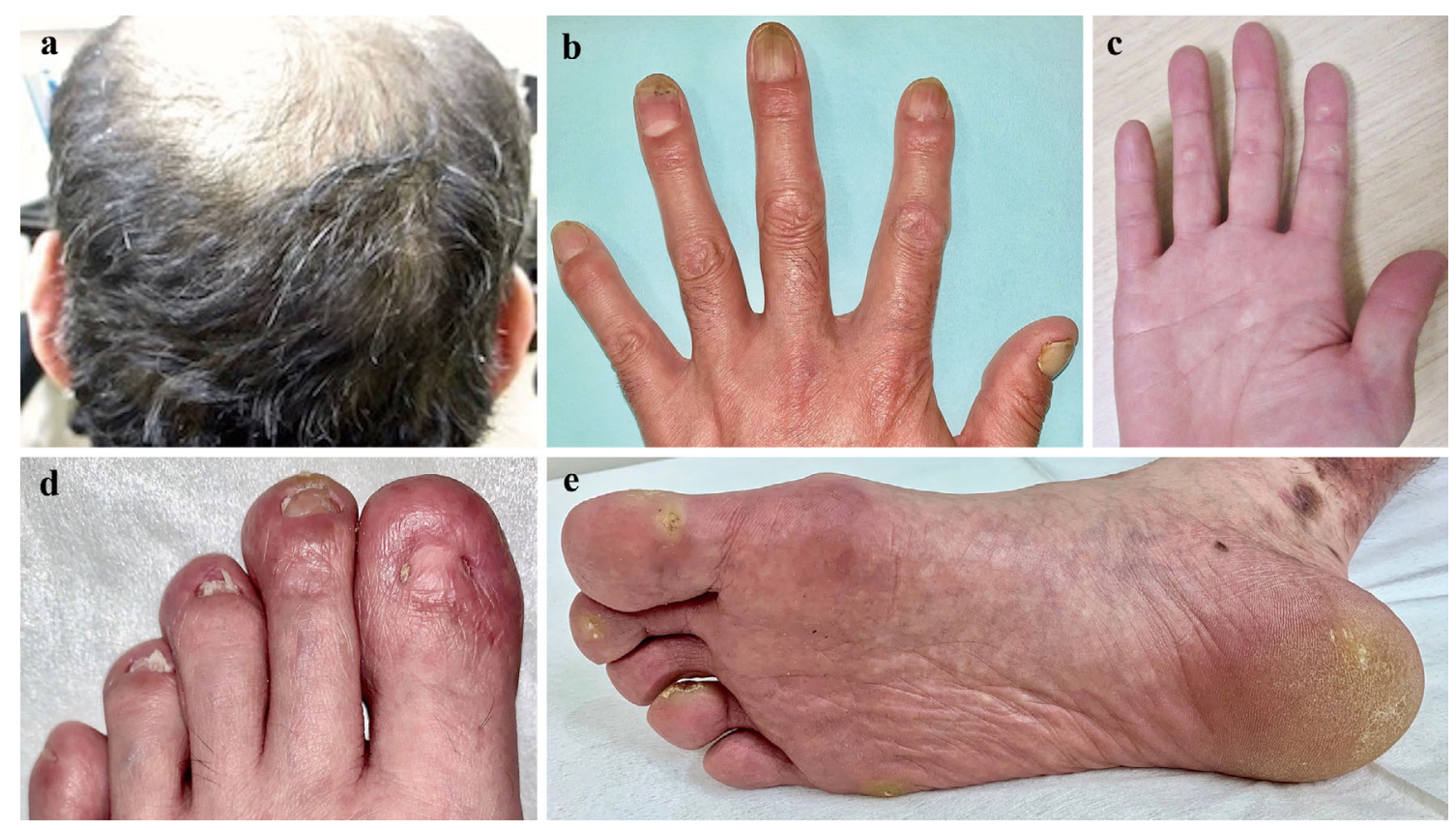

Figure 3. The patient's physical findings showing curly hair (a), thick, white, and dystrophic finger nails (b), brittle and detached toe nails (d), and mild focal keratosis of the palms and soles of feet (c, e).

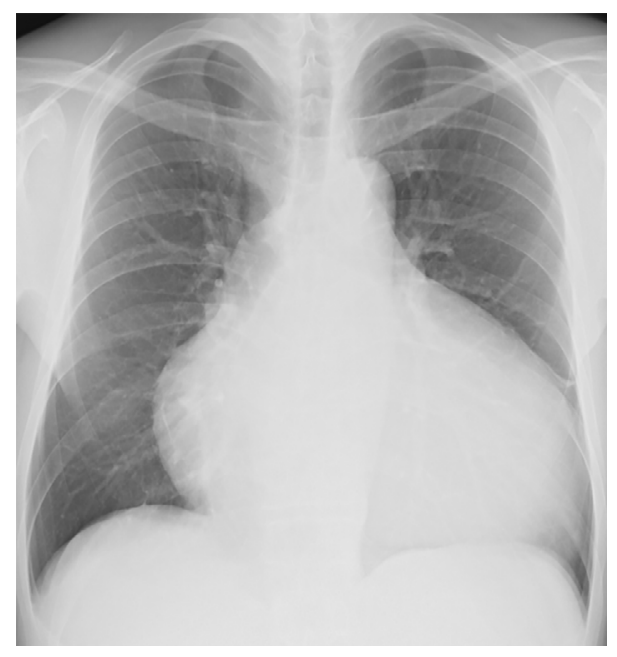

Figure 4. A chest X-ray image. A chest radiograph demonstrating marked cardiomegaly and vascular redistribution as early signs of heart failure.

right ventricular cardiomyopathy (ARVC) with left ventricular involvement by meeting two major and two minor criteria (8).

The patient experienced non-sustained ventricular tachycardias during admission and underwent implantation of an cardioverter defibrillator as a class I indication (9). He was discharged on day 31, and his BNP level decreased to 482 $\mathrm{pg} / \mathrm{mL}$. A continued dermatological examination in an outpatient setting provided a definite diagnosis of junctional EB (JEB). Candidate genes for JEB, including the desmoplakin gene (DSP) and desmoglein gene (DSG), were extensively investigated; however, no mutations were identified. Electron microscopy identified no changes indicative of specific dis- orders.

\section{Discussion}

Disorganized desmosome complexes impair cellular integrity and accommodability to stress. This induces disorders in multiple organs, especially those susceptible to stress, such as the heart and the skin (10). Three desmosomal genes have been identified to cause this type of cardiocutaneous syndrome: the plakoglobin gene (JUP) causing NAXOS disease, the DSP causing Carvajal syndrome, and the desmocollin-2 gene (DSC2) (11). Although small differences exist, they share the characteristic triad of cardiomyopathy, palmoplantar keratosis, and woolly hair. Diseases compatible with the triad are thus called NAXOS-Carvajal syndrome and are thought to be associated with desmosomal gene disruption.

Cardiomyopathy in NAXOS disease is characterized by right-dominant ventricular dilatation, hypokinesis, and tachyarrhythmia, which are compatible with ARVC (3). In contrast, Carvajal syndrome predominantly involves the left ventricle, resembling dilated cardiomyopathy (4). This ventricular preponderance initially served to define each syndrome. However, the distinction was later considered ambiguous, as even mutations in the same gene or within the same gene family can affect both ventricles $(11,12)$. Similarly, ARVC, originally regarded as a pure right ventricular disease, were later found to involve the left ventricle. Such variant ARVCs were once named left-dominant arrhythmogenic cardiomyopathy (LDAC) (13). Now these diseases may be collectively called as arrhythmogenic cardiomyopathy, as the same gene can affect both ventricles (14). In this 


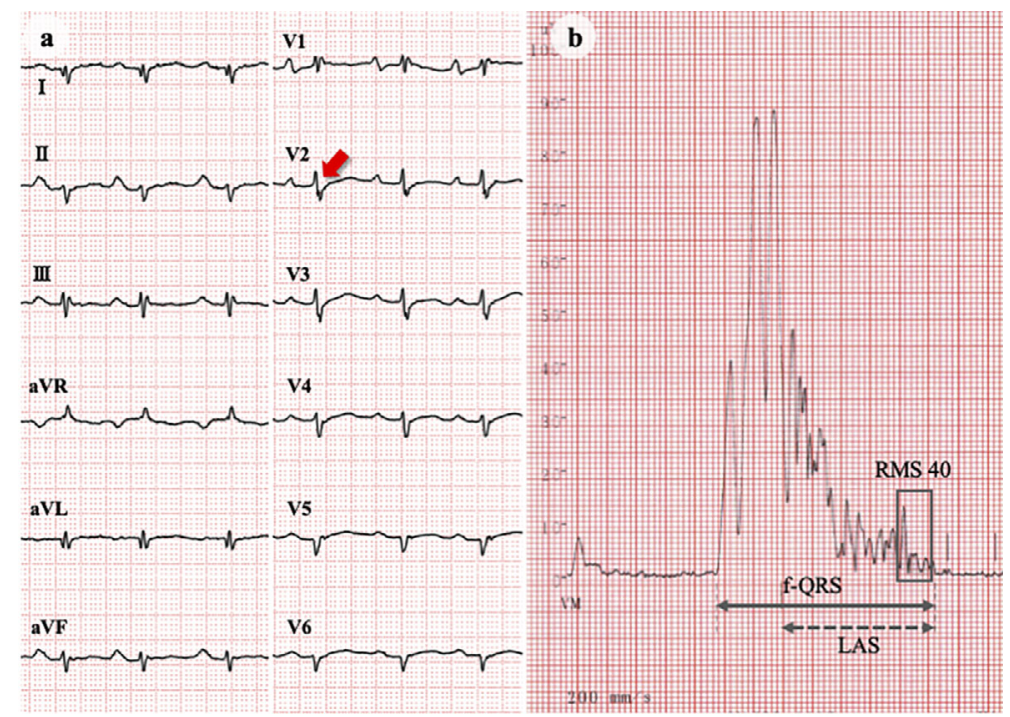

Figure 5. ECG and signal-averaged ECG. ECG showing low voltage, first-degree atrioventricular block, abnormal Q waves in I/aVL/V5-6, and epsilon waves (arrow) in the precordial leads (a). Signalaveraged ECG indicating positive late potentials (b). Filtered QRS duration (f-QRS): 186 ms (upper normal limit: $114 \mathrm{~ms}$ ); low amplitude signal duration (LAS): $131 \mathrm{~ms}$ (upper normal limit: $38 \mathrm{~ms}$ ); root-mean-square voltage during $40 \mathrm{~ms}$ before QRS termination (RMS 40): $5 \mu \mathrm{V}$ (lower normal limit: $20 \mu \mathrm{V})$. ECG: electrocardiogram
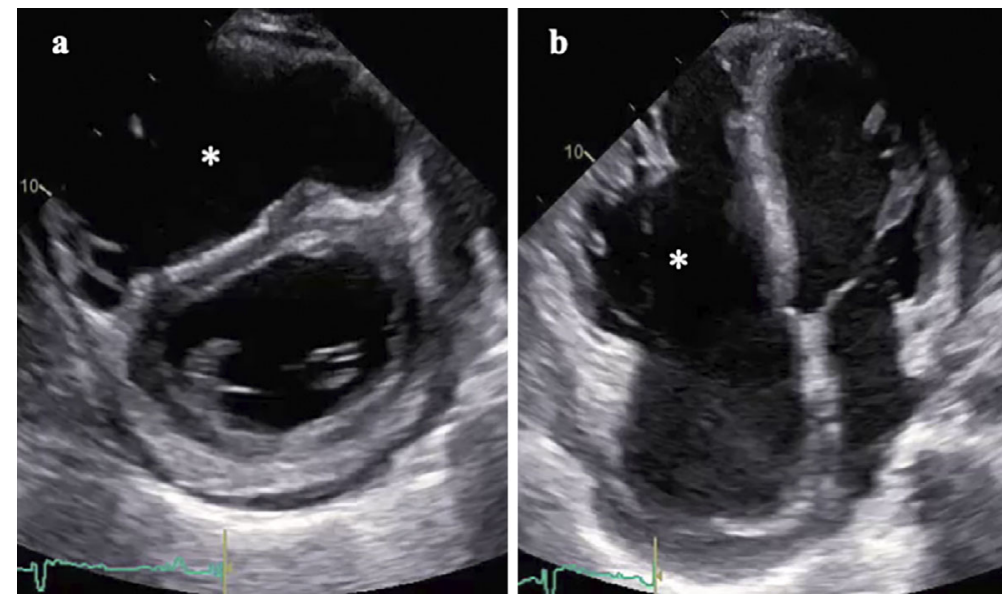

Figure 6. Echocardiography. Parasternal short axis (a) and apical four-chamber images (b) exhibiting right ventricular dilatation and dysfunction (asterisk) with flattened ventricular septum. Severe tricuspid regurgitation and left ventricular dilatation/dysfunction were also observed.

context, the biventricular cardiomyopathy in the present case was diagnosed as a common cardiac presentation of NAXOS-Carvajal syndrome. In addition, the myopathy can also be diagnosed as ARVC and LDAC, or arrhythmogenic cardiomyopathy.

Variants of NAXOS-Carvajal syndrome have been reported from around the world, regardless of ethnicity (Table 1). Autosomal recessive or unknown inheritance predominates in cases with consanguineous parents. All cases have shown the triad with minor variation in severity and distribution. Half of cases had additional features, with nail or tooth abnormalities predominant $(3,4,6,7,12,15-26)$. Of note, both the first cases of NAXOS disease and Carvajal syndrome shared curved fingernails $(3,4)$. Subsequent cases were also reported to have nail disorders, such as thickening, dystrophy, white change, or brittleness, although none of these were considered fourth traits of NAXOS-Carvajal syndrome $(7,12,15,17-24,26)$. Tooth agenesis was first implicated in the syndrome in the first case with autosomaldominant transmission (6). Intriguingly, most cases with additional tooth abnormalities have shown autosomal-dominant inheritance, regardless of nail findings (7, 21, 24-26).

Blisters have been reported as a cutaneous variant in only four cases (Table 2) $(12,18,19,27)$. Common features were homozygous DSP mutations, biventricular and nail involvement, and mild keratosis. While the blisters varied in size or distribution, the involvement of teeth was indeterminate. The findings of the present case were consistent with these char- 

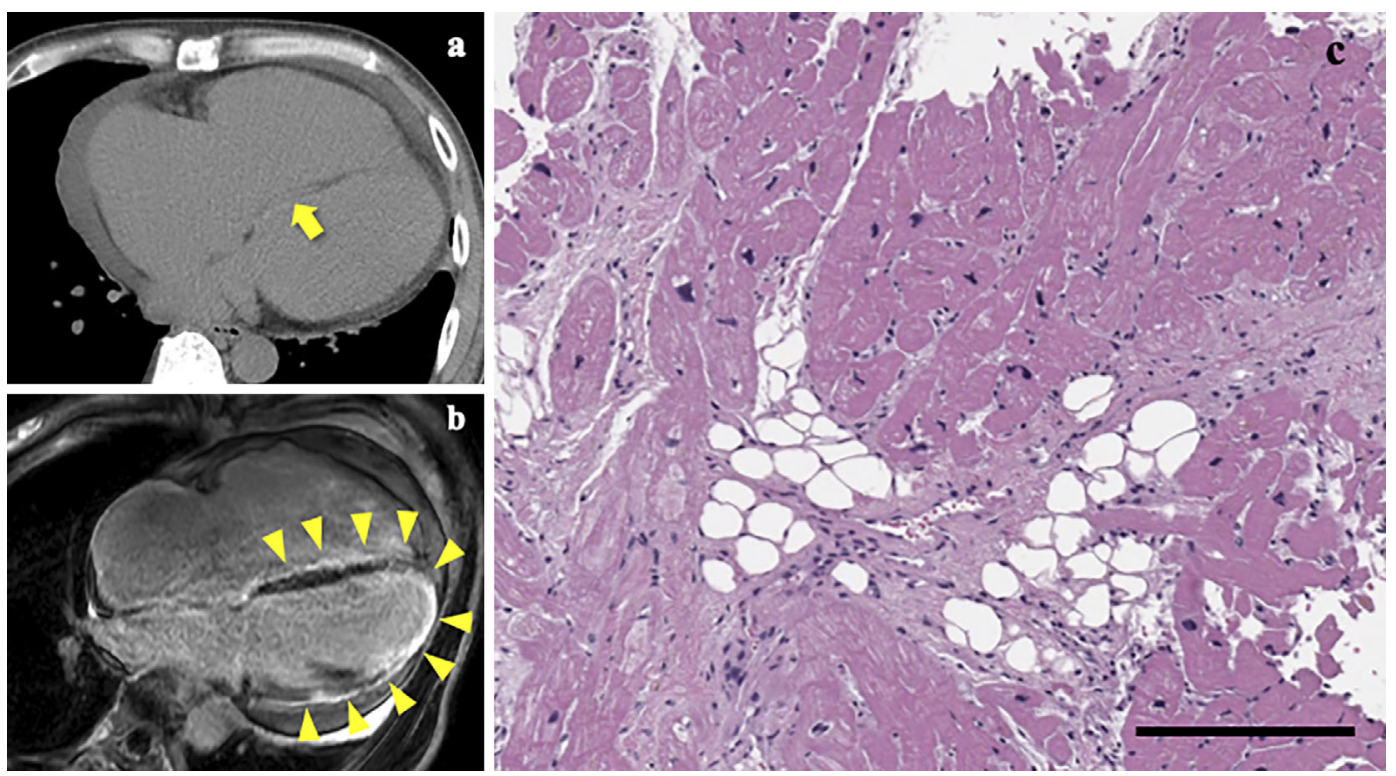

Figure 7. CT scans, MR images and endomyocardial biopsy specimens. CT scans (a) and MR images (b) depicting fatty infiltration (arrow) and fibrosis (arrowheads) of the ventricular septum, respectively. Fibrosis of the left ventricle was also identified on MR images (b). Light microscopic examination of the right ventricle tissues demonstrating extensive fibro-fatty replacement of the cardiac myocytes (c). Scale bar, $200 \mu \mathrm{m}$.

acteristics. However, its novelty was accentuated in that the patient lacked a DSP mutation and exhibited a relatively large bulla that was distributed throughout his body.

The older onset age of HF in our case not only suggests a better prognosis but also has pathophysiological implications. The age at the onset in patients with a DSC2 mutation is also older than in those with DSP mutations. This may be better explained by the interaction between desmocollin and desmoplakin than by the direct disruption of desmocollin (11). Thus, in addition to mechanical disruption of the desmosome complex, altered cell signaling pathways between desmoplakin and other desmosomal components or factors associated with desmosomes may underlie disease formation.

There are only three known causative genes for NAXOSCarvajal syndrome, but as exemplified in a case with DSC2 mutation, all of the genes related to the desmosome complex have the potential to induce the phenotype. Indeed, there have been several reports showing the NAXOS-Carvajal phenotype in which the responsible gene was unclear but not $\operatorname{DSP}(22,23)$. Furthermore, the genotype-phenotype association varies according to the site or mode of the mutation among cases with DSP mutations. These facts underscore the genetic heterogeneity of this syndrome. As we only examined DSP and DSGs in the present case, a thorough investigation of other related genes may elucidate the precise mechanism.

Given the aggregation patterns of curly hair and HF, the disease may be transmitted through autosomal-dominant inheritance. This notion is consistent with the fact that most cases of variant Carvajal syndrome with additional abnormalities of the teeth are autosomal-dominant, whereas classi- cal ones are autosomal-recessive (25). However, this is only speculative, and other possibilities, including de novo or compound heterogeneous mutations with or without consanguinity, may underlie the disease expression. Furthermore, the penetrance or Lyon hypothesis can also affect the phenotypic expression, both of which are underrepresented in NAXOS-Carvajal syndrome with additional features.

Genes causing EB may also affect multiple organs, including the heart, as in cases with lethal acantholytic EB that represent cardiomyopathy or $\operatorname{HF}(28,29)$. EB is classified into four subcategories: EB simplex, JEB, dystrophic $\mathrm{EB}$, or a mixture thereof (30). As electron microscopy findings were indeterminate for the classification, JEB was chiefly diagnosed by physical findings. The presence of nail dystrophy and lack of palmoplantar bullas were inconsistent with EB simplex, while the lack of scarring or milium on and around the healed bullas contradicted dystrophic EB. We therefore examined the gene abnormalities known to induce JEB. Two independent dermatologists clinically established the diagnosis. However, an extensive analysis identified no gene mutations for major JEB subtypes, except for two rare variants without heart involvement. This suggested that JEB-related genes did not contribute to the NAXOSCarvajal phenotype in the present case.

This case highlights the fact that NAXOS-Carvajal syndrome can be accompanied by additional bullous lesions and brittle nails through unknown inheritable gene mutations or modes of transmission. This case also demonstrates that bulla and brittle nails serve as a critical clue for identifying serious cardiac conditions that may otherwise go undetected.

The patient provided his written informed consent to publish 
Table 1. NAXOS-Carvajal Phenotype with or without Additional Features.

\begin{tabular}{|c|c|c|c|c|c|c|c|c|c|}
\hline \multirow[b]{2}{*}{ Reference } & \multirow[b]{2}{*}{ Ethnicity } & \multirow[b]{2}{*}{$\begin{array}{l}\text { Consan- } \\
\text { guinity }\end{array}$} & \multicolumn{3}{|c|}{ Gene abnormalities } & \multicolumn{4}{|c|}{ Organ involvement } \\
\hline & & & $\begin{array}{c}\text { Inheri- } \\
\text { tance }\end{array}$ & Genes & Mutation(s) & Heart & Skin & Hair & Others \\
\hline \multicolumn{10}{|c|}{ NAXOS-Carvajal phenotype with additional features } \\
\hline \multicolumn{10}{|c|}{ bullous phenotype: } \\
\hline (18) & Brazilian & No & $\mathrm{AR}^{\#}$ & DSP & $\begin{array}{l}\text { c. } 2516 \text { del } 4 \\
\text { c.3971del4 }\end{array}$ & $\mathrm{BiV}$ & PPK, striate & $\begin{array}{l}\text { near-total } \\
\text { alopecia }\end{array}$ & thick and dystrophied nails \\
\hline (19) & Finnish & No & $\mathrm{AR}^{\#}$ & DSP & $\begin{array}{l}\text { c.7964C }>\mathrm{A} \\
\text { c.6310delA }\end{array}$ & $\mathrm{BiV}$ & PPK & $\begin{array}{l}\text { woolly, short, } \\
\text { sparce }\end{array}$ & $\begin{array}{l}\text { dystrophied and detached nails, enamel } \\
\text { dysplasia }\end{array}$ \\
\hline (12) & Palestinian & Yes & $\mathrm{AR}$ & DSP & c. $7111 \mathrm{C}>\mathrm{A}$ & $\mathrm{RV}, \mathrm{BiV}$ & $\begin{array}{c}\text { PPK, } \\
\text { epidermolytic }\end{array}$ & woolly & toe onychogryphosis \\
\hline present case & Japanese & No & $\mathrm{U}$ & $\mathrm{U}^{* 1}$ & $\mathrm{U}$ & $\mathrm{BiV}$ & PPK, mild & $\begin{array}{l}\text { curly auburn } \\
\text { change }\end{array}$ & $\begin{array}{l}\text { brittle nails, } \\
\text { leukonychia }\end{array}$ \\
\hline \multicolumn{10}{|c|}{ non-bullous phenotype: } \\
\hline (3) & Greek & $\mathrm{U}$ & $\mathrm{AR}$ & $\mathrm{U}$ & $\mathrm{U}$ & $\mathrm{BiV}$ & PPK & steel wire-like & $\begin{array}{l}\text { curved nails } \\
\text { short fingers }\end{array}$ \\
\hline (15) & Indian & Yes & $\mathrm{U}$ & $\mathrm{U}$ & $\mathrm{U}$ & LV & PPK & $\begin{array}{l}\text { curly, soft and } \\
\text { woolly alopecia }\end{array}$ & $\begin{array}{l}\text { thickened and } \\
\text { deformed nails }\end{array}$ \\
\hline (4) & Ecuadorian & No & AR & $\mathrm{U}$ & $\mathrm{U}$ & LV & PPK & woolly & fingernail clubbing \\
\hline (16) & Indian & Yes & $\mathrm{AR}$ & $\mathrm{U}$ & $\mathrm{U}$ & $\mathrm{BiV}$ & PPK & woolly & cleft lip and palate \\
\hline (6) & $\mathrm{U}$ & $\mathrm{U}$ & $\mathrm{AD}$ & DSP & $\begin{array}{l}30 \mathrm{bp} \\
\text { insertion }^{* 2}\end{array}$ & $\mathrm{BiV}$ & $\begin{array}{l}\text { PPK, focal and } \\
\text { psoriasiform }\end{array}$ & woolly & tooth agenesis \\
\hline (20) & Indian & Yes & $\mathrm{U}$ & $\mathrm{U}$ & $\mathrm{U}$ & $\begin{array}{l}\text { epsilon waves } \\
\mathrm{T} \text { wave inversion }\end{array}$ & PPK, striate & woolly & clubbed finger nails middle lobe syndrome \\
\hline (21) & $\mathrm{U}$ & $\mathrm{U}$ & $\mathrm{AD}$ & DSP & c. $1790 \mathrm{C}>\mathrm{T}$ & $\mathrm{BiV}$ & PPK & woolly & $\begin{array}{l}\text { fragile nails } \\
\text { tooth agenesis }\end{array}$ \\
\hline $\begin{array}{l}(17) \\
(22)\end{array}$ & $\mathrm{U}$ & No & $\mathrm{U}$ & $\mathrm{U}^{* 1}$ & $\mathrm{U}$ & LV & PPK & wavy and wiry & $\begin{array}{l}\text { small, white and thick nails } \\
\text { periodontitis, hypodontia }\end{array}$ \\
\hline (23) & $\mathrm{U}$ & $\mathrm{U}$ & $\mathrm{U}$ & $\mathrm{U}^{* 3}$ & $\mathrm{U}$ & LV & PPK & woolly & thick and fragile nails tooth agenesis \\
\hline (7) & Caucasian & $\mathrm{U}$ & $\mathrm{AD}$ & DSP & c. $1691 \mathrm{C}>\mathrm{T}$ & $\mathrm{BiV}$ & PPK & woolly & $\begin{array}{c}\text { leukonychia } \\
\text { oligodontia }\end{array}$ \\
\hline (24) & Caucasian & No & $\mathrm{AD}$ & DSP & c. $1748 \mathrm{~T}>\mathrm{C}$ & $\mathrm{BiV}$ & PPK & woolly & dystrophied nails \\
\hline (24) & Caucasian & No & $\mathrm{AD}$ & DSP & c. $1691 \mathrm{C}>\mathrm{T}$ & $\mathrm{BiV}$ & PPK, slight & $\begin{array}{l}\text { curly and } \\
\text { woolly }\end{array}$ & $\begin{array}{l}\text { toe leukonychia } \\
\text { tooth agenesis }\end{array}$ \\
\hline (25) & Caucasian & No & $\mathrm{AD}$ & $\mathrm{U}$ & $\mathrm{U}$ & LV apical LVHT & PPK & $\begin{array}{l}\text { woolly and } \\
\text { darkened }\end{array}$ & tooth agenesis \\
\hline (26) & Lebanese & $\mathrm{U}$ & $\mathrm{AD}$ & DSP & c. $1865 \mathrm{~T}>\mathrm{C}$ & LV & PPK & woolly & $\begin{array}{l}\text { leukonychia } \\
\text { tooth agenesis }\end{array}$ \\
\hline \multicolumn{10}{|c|}{ NAXOS-Carvajal phenotype without additional features } \\
\hline \multicolumn{10}{|c|}{ bullous phenotype: } \\
\hline (27) & Arabic & Yes & AR & DSP & c. $7402 \mathrm{G}>\mathrm{C}$ & RV & $\begin{array}{l}\text { no PPK } \\
\text { dry skin }\end{array}$ & woolly & - \\
\hline \multicolumn{10}{|c|}{ non-bullous phenotype: } \\
\hline (31) & Ecuadorian & Yes & $\mathrm{AR}$ & DSP & c.7901delG & LV & PPK, striate & $\begin{array}{l}\text { curly and } \\
\text { woolly }\end{array}$ & - \\
\hline (5) & Greek & $\mathrm{U}$ & $\mathrm{AR}$ & JUP & $\begin{array}{l}\text { c. } 2157 \_2158 \\
\text { delTG }\end{array}$ & $\mathrm{RV}$ & keratosis & woolly & - \\
\hline (32) & Asian-Indian & $\mathrm{U}$ & de novo & $\mathrm{U}$ & $\mathrm{U}$ & $\mathrm{RV}$ & PPK & woolly & - \\
\hline (33) & Turkish & Yes & $\mathrm{AR}$ & $\begin{array}{l}\text { DSP } \\
\text { JUP }\end{array}$ & $\begin{array}{l}\text { c. } 3799 \mathrm{C}>\mathrm{T} \\
\text { c. } 2089 \mathrm{~T}>\mathrm{A}\end{array}$ & $\mathrm{BiV}$ & PPK & woolly & - \\
\hline (34) & Arabic & Yes & $\mathrm{AR}$ & $\mathrm{U}$ & $\mathrm{U}$ & $\mathrm{BiV}$ & PPK & curly & - \\
\hline (35) & Azerbaijan & Yes & $\mathrm{AR}$ & DSP & $\begin{array}{l}\text { 2-bp deletion } \\
\text { of exon } 23\end{array}$ & $\begin{array}{l}\text { BiV } \\
\text { BiVHT }\end{array}$ & PPK & woolly & - \\
\hline (36) & Spanish & $\mathrm{U}$ & $\mathrm{U}$ & $\mathrm{U}^{* 3}$ & U & RV & PPK & woolly & - \\
\hline (37) & $\mathrm{U}$ & Yes & $\mathrm{AR}$ & $\mathrm{U}$ & $\mathrm{U}$ & RV & PPK & woolly & - \\
\hline (11) & Pakistani & Yes & $\mathrm{AR}$ & DSC2 & c. 1841 delG & $\mathrm{BiV}$ & PPK, mild & woolly & - \\
\hline (38) & $\mathrm{U}$ & Yes & $\mathrm{AR}$ & DSP & $\begin{array}{l}\text { c.5208_5209 } \\
\text { delAG }\end{array}$ & $\mathrm{BiV}$ & $\begin{array}{l}\text { PPK, } \\
\text { acantholytic }\end{array}$ & woolly & - \\
\hline (39) & Indian & Yes & $\mathrm{AR}$ & DSP & c. $3901 \mathrm{C}>\mathrm{T}$ & $\mathrm{BiV}$ & PPK & $\begin{array}{l}\text { woolly, curly, } \\
\text { brittle }\end{array}$ & - \\
\hline (40) & non-Greek & $\mathrm{U}$ & $\mathrm{U}$ & $\mathrm{U}$ & $\mathrm{U}$ & $\mathrm{RV}$ & PPK & woolly & - \\
\hline (41) & Turkish & Yes & AR & DSP & c.7780delT & $\mathrm{BiV}$ & PPK & woolly & - \\
\hline$(42)$ & Italian & $\mathrm{U}$ & $\mathrm{AD}$ & DSP & c. $878 \mathrm{~A}>\mathrm{T}$ & $\mathrm{BiV}$ & keratosis & & - \\
\hline (12) & Palestinian & Yes & $\mathrm{AR}$ & DSP & c.3924delG & $\mathrm{BiV}$ & keratosis & woolly & - \\
\hline
\end{tabular}

\#compound heterogeneous inheritance.

${ }^{*}$ no DSP gene mutation was detected.

*2 c.1823_1824insACAGTCTCAGTTCACCGATGCCCGGAAAAT.

${ }^{* 3}$ no mutations in DSP nor JUP genes were identified.

AR: autosomal recessive inheritance, AD: autosomal dominant inheritance, BiV: biventricular involvement, BiVHT: biventricular hypertrabeculation/noncompaction, DSP: desmoplakin, JUP: plakoglobin, LV: left ventricular involvement, LVHT: left ventricular hypertrabeculation/noncompaction, RV: right ventricular involvement, U: unknown 
Table 2. Details of Organ Involvement in NAXOS-Carvajal Syndrome Associated with Blisters and Nail Anomalies.

\begin{tabular}{|c|c|c|c|c|c|c|}
\hline \multirow{2}{*}{ Reference } & \multicolumn{6}{|c|}{ Organ involvement } \\
\hline & Heart & Blisters & PPK & Hair & Nails & Teeth \\
\hline 27 & $\begin{array}{c}\text { mild RV } \\
\text { dilatation } \\
\text { VT of RV origin }\end{array}$ & $\begin{array}{l}\text { pemphigus foliaceous-like } \\
\text { vesicles on the extremities }\end{array}$ & none & woolly & not reported & not reported \\
\hline 18 & $\begin{array}{l}\text { BiV dilatation } \\
\text { and systolic } \\
\text { dysfunction }\end{array}$ & $\begin{array}{l}\text { blisters and erosions, } \\
\text { especially at sites of } \\
\text { mechanical trauma }\end{array}$ & $\begin{array}{l}\text { focal and striate } \\
\text { with fissuring }\end{array}$ & $\begin{array}{l}\text { near-total } \\
\text { alopecia }\end{array}$ & $\begin{array}{l}\text { thick and } \\
\text { dystrophic }\end{array}$ & not reported \\
\hline 19 & BiV dilatation & $\begin{array}{l}\text { superficial, mucocutaneous, } \\
\text { scalp and face blisters } \\
\text { blistering only develops } \\
\text { after severe mechanical } \\
\text { stress since } 6 \text { years of age }\end{array}$ & $\begin{array}{c}\text { localized } \\
\text { minimal palmar } \\
\text { involvement }\end{array}$ & $\begin{array}{l}\text { woolly and } \\
\text { sparse }\end{array}$ & $\begin{array}{l}\text { thick, detached } \\
\text { and dystrophic }\end{array}$ & $\begin{array}{l}\text { enamel } \\
\text { dysplasia }\end{array}$ \\
\hline 12 & $\begin{array}{l}\text { severe RV or } \\
\text { BiV dysfunction } \\
\text { SCD in BiV } \\
\text { involvement }\end{array}$ & $\begin{array}{l}\text { epidermolytic plantar } \\
\text { blisters and erythema, } \\
\text { followed by keratoderma }\end{array}$ & $\begin{array}{l}\text { mild palmar } \\
\text { keratosis plantar } \\
\text { keratosis in } \\
\text { pressure areas }\end{array}$ & $\begin{array}{l}\text { woolly, rough, } \\
\text { light-colored }\end{array}$ & onychogryphosis & not reported \\
\hline present case & $\begin{array}{l}\text { BiV dilatation } \\
\text { and systolic } \\
\text { dysfunction }\end{array}$ & $\begin{array}{l}\text { epidermolytic bulla, } \\
\text { erosions and pigmentations } \\
\text { throughout the body, not on } \\
\text { the palms and soles }\end{array}$ & mild and focal & $\begin{array}{l}\text { curly, fine } \\
\text { brown change }\end{array}$ & $\begin{array}{l}\text { thick, detached } \\
\text { and dystrophic }\end{array}$ & normal \\
\hline
\end{tabular}

BiV: biventricular, LV: left ventricle, PPK: palmoplantar keratosis, RV: right ventricle, SCD: sudden cardiac death, VT: ventricular tachycardia

his case, including the associated images.

\section{The authors state that they have no Conflict of Interest (COI).}

Takanori Sato and Sho Okada contributed equally to this work.

\section{References}

1. Griffing G. Images in clinical medicine. Frank's sign. N Engl J Med 370: e15, 2014.

2. Abdelmalek NF, Gerber TL, Menter A. Cardiocutaneous syndromes and associations. J Am Acad Dermatol 46: 161-183, quiz 183-186, 2002.

3. Protonotarios N, Tsatsopoulou A, Patsourakos $\mathrm{P}$, et al. Cardiac abnormalities in familial palmoplantar keratosis. Br Heart J 56: 321326, 1986.

4. Carvajal-Huerta L. Epidermolytic palmoplantar keratoderma with woolly hair and dilated cardiomyopathy. J Am Acad Dermatol 39: 418-421, 1998.

5. McKoy G, Protonotarios N, Crosby A, et al. Identification of a deletion in plakoglobin in arrhythmogenic right ventricular cardiomyopathy with palmoplantar keratoderma and woolly hair (Naxos disease). Lancet 355: 2119-2124, 2000.

6. Norgett EE, Lucke TW, Bowers B, Munro CS, Leigh IM, Kelsell DP. Early death from cardiomyopathy in a family with autosomal dominant striate palmoplantar keratoderma and woolly hair associated with a novel insertion mutation in desmoplakin. J Invest Dermatol 126: 1651-1654, 2006.

7. Boule S, Fressart V, Laux D, et al. Expanding the phenotype associated with a desmoplakin dominant mutation: Carvajal/Naxos syndrome associated with leukonychia and oligodontia. Int J Cardiol 161: 50-52, 2012.

8. Marcus FI, McKenna WJ, Sherrill D, et al. Diagnosis of arrhythmogenic right ventricular cardiomyopathy/dysplasia: proposed modification of the Task Force Criteria. Eur Heart J 31: 806-814, 2010.
9. Corrado D, Wichter T, Link MS, et al. Treatment of arrhythmogenic right ventricular cardiomyopathy/dysplasia: an international task force consensus statement. Eur Heart J 36: 3227-3237, 2015.

10. Bardawil T, Khalil S, Bergqvist C, et al. Genetics of inherited cardiocutaneous syndromes: a review. Open Heart 3: e000442, 2016.

11. Simpson MA, Mansour S, Ahnood D, et al. Homozygous mutation of desmocollin-2 in arrhythmogenic right ventricular cardiomyopathy with mild palmoplantar keratoderma and woolly hair. Cardiology 113: 28-34, 2009.

12. Molho-Pessach V, Sheffer S, Siam R, et al. Two novel homozygous desmoplakin mutations in Carvajal syndrome. Pediatr Dermatol 32: 641-646, 2015.

13. Sen-Chowdhry S, Syrris P, Prasad SK, et al. Left-dominant arrhythmogenic cardiomyopathy: an under-recognized clinical entity. J Am Coll Cardiol 52: 2175-2187, 2008.

14. Corrado D, Basso C, Judge DP. Arrhythmogenic cardiomyopathy. Circ Res 121: 784-802, 2017.

15. Rao BH, Reddy IS, Chandra KS. Familial occurrence of a rare combination of dilated cardiomyopathy with palmoplantar keratoderma and curly hair. Indian Heart J 48: 161-162, 1996.

16. Adhisivam B, Mahadevan S. Naxos disease. Indian J Pediatr 73 : 359-360, 2006.

17. Kolar AJ, Milroy CM, Day PF, Suvarna SK. Dilated cardiomyopathy and sudden death in a teenager with palmar-plantar keratosis (occult Carvajal syndrome). J Forensic Leg Med 15: 185-188, 2008.

18. Tanaka A, Lai-Cheong JE, Cafe ME, et al. Novel truncating mutations in PKP1 and DSP cause similar skin phenotypes in two Brazilian families. Br J Dermatol 160: 692-697, 2009.

19. Mahoney MG, Sadowski S, Brennan D, et al. Compound heterozygous desmoplakin mutations result in a phenotype with a combination of myocardial, skin, hair, and enamel abnormalities. J Invest Dermatol 130: 968-978, 2010.

20. Meera G, Prabhavathy D, Jayakumar S, Tharini G. Naxos disease in two siblings. Int J Trichology 2: 53-55, 2010.

21. Chalabreysse L, Senni F, Bruyere P, et al. A new hypo/oligodontia syndrome: Carvajal/Naxos syndrome secondary to desmoplakindominant mutations. J Dent Res 90: 58-64, 2011.

22. Barber S, Day P, Judge M, Toole EO, Fayle S. Variant Carvajal 
syndrome with additional dental anomalies. Int J Paediatr Dent 22: 390-396, 2012.

23. Nehme N, El Malti R, Roux-Buisson N, Caignault JR, Bouvagnet P. Evidence for genetic heterogeneity in Carvajal syndrome. Cell Tissue Res 348: 261-264, 2012.

24. Keller DI, Stepowski D, Balmer C, et al. De novo heterozygous desmoplakin mutations leading to Naxos-Carvajal disease. Swiss Med Wkly 142: w13670, 2012.

25. Stollberger C, Vujic I, Wollmann E, Freudenthaler J, Finsterer J. Carvajal syndrome with oligodontia, hypoacusis, recurrent infections, and noncompaction. Int J Cardiol 203: 825-827, 2016.

26. Bitar F, Najjar T, Hayashi R, et al. A novel heterozygous mutation in desmoplakin gene in a Lebanese patient with Carvajal syndrome and tooth agenesis. J Eur Acad Dermatol Venereol 30: e217-e219, 2016.

27. Alcalai R, Metzger S, Rosenheck S, Meiner V, Chajek-Shaul T. A recessive mutation in desmoplakin causes arrhythmogenic right ventricular dysplasia, skin disorder, and woolly hair. J Am Coll Cardiol 42: 319-327, 2003.

28. Jonkman MF, Pasmooij AM, Pasmans SG, et al. Loss of desmoplakin tail causes lethal acantholytic epidermolysis bullosa. Am J Hum Genet 77: 653-660, 2005.

29. Bolling MC, Veenstra MJ, Jonkman MF, et al. Lethal acantholytic epidermolysis bullosa due to a novel homozygous deletion in DSP: expanding the phenotype and implications for desmoplakin function in skin and heart. Br J Dermatol 162: 1388-1394, 2010.

30. Fine JD, Bruckner-Tuderman L, Eady RA, et al. Inherited epidermolysis bullosa: updated recommendations on diagnosis and classification. J Am Acad Dermatol 70: 1103-1126, 2014.

31. Norgett EE, Hatsell SJ, Carvajal-Huerta L, et al. Recessive mutation in desmoplakin disrupts desmoplakin-intermediate filament interactions and causes dilated cardiomyopathy, woolly hair and keratoderma. Hum Mol Genet 9: 2761-2766, 2000.

32. Sajeev CG, Francis J, Sankar V, Vasudev B, Venugopal K. Images in cardiovascular medicine. Ventricular tachycardia: the spectrum continues to broaden: report of Naxos disease. Circulation 114 e60-e61, 2006.

33. Uzumcu A, Norgett EE, Dindar A, et al. Loss of desmoplakin isoform I causes early onset cardiomyopathy and heart failure in a Naxos-like syndrome. J Med Genet 43: e5, 2006.
34. Kilic T, Babaoglu K, Aygun F, et al. Biventricular involvement in a Turkish boy with palmoplantar hyperkeratosis and curly hair, an unusual presentation of Naxos-Carvajal syndrome. Int J Cardiol 115: e122-e125, 2007.

35. Prompona M, Kozlik-Feldmann R, Mueller-Hoecker J, Reiser M, Huber A. Images in cardiovascular medicine. Magnetic resonance imaging characteristics in Carvajal syndrome (variant of Naxos disease). Circulation 116: e524-e530, 2007.

36. Alonso-Orgaz S, Zamorano-Leon JJ, Fernandez-Arquero M, et al. Case report of a Spanish patient with arrhythmogenic right ventricular cardiomyopathy and palmoplantar keratoderma without plakoglobin and desmoplakin gene modifications. Int $\mathrm{J}$ Cardiol 118: 275-277, 2007.

37. Rai R, Ramachandran B, Sundaram VS, Rajendren G, Srinivas CR. Naxos disease: a rare occurrence of cardiomyopathy with woolly hair and palmoplantar keratoderma. Indian J Dermatol Venereol Leprol 74: 50-52, 2008.

38. Williams T, Machann W, Kuhler L, et al. Novel desmoplakin mutation: juvenile biventricular cardiomyopathy with left ventricular non-compaction and acantholytic palmoplantar keratoderma. Clin Res Cardiol 100: 1087-1093, 2011.

39. Krishnamurthy S, Adhisivam B, Hamilton RM, Baskin B, Biswal N, Kumar M. Arrhythmogenic dilated cardiomyopathy due to a novel mutation in the desmoplakin gene. Indian J Pediatr 78: 866869, 2011.

40. Noain JA, Golet AC, Calzada JN, Mellado AM, Duarte JM. Living after sudden death: a case report of Naxos disease. Indian J Crit Care Med 16: 207-209, 2012.

41. Rasmussen TB, Hansen J, Nissen PH, et al. Protein expression studies of desmoplakin mutations in cardiomyopathy patients reveal different molecular disease mechanisms. Clin Genet 84: 2030, 2013

42. Tomberli B, Fornaro A, Bardi S, et al. A novel desmoplakin dominant mutation responsible for Carvajal/Naxos syndrome identified by exome sequencing. Eur Heart J 34 (Suppl): 528, 2013.

The Internal Medicine is an Open Access journal distributed under the Creative Commons Attribution-NonCommercial-NoDerivatives 4.0 International License. To view the details of this license, please visit (https://creativecommons.org/licenses/ by-nc-nd/4.0/).

(C) 2021 The Japanese Society of Internal Medicine Intern Med 60: 1119-1126, 2021 